\title{
The Effects of the External Environment on Internal Management Strategies within Micro, Small and Medium Enterprises; Kenyan Case
}

\author{
W L Njanja \\ School of Business, Kabarak University (ex student, UNISA) \\ Nakuru-Eldama Ravine Highway \\ Private Bag - 20157 KABARAK, Kenya \\ E-mail: lnjanja@kabarak.ac.ke \\ Martin Ogutu \\ Department of Business Administration \\ University of Nairobi, Kenya \\ E-mail: Ogutum@uonbi.ac.ke \\ Rene' Pellisier \\ Department of Business Management, University of South Africa \\ Pretoria, South Africa \\ E-mail: Pellir@unisa.ac.za
}

$\begin{array}{ll}\text { Received: August 4, } 2011 & \text { Accepted: October 19, } 2011 \quad \text { Published: February 1, } 2012 \\ \text { doi:10.5539/ijbm.v7n3p194 } & \text { URL: http://dx.doi.org/10.5539/ijbm.v7n3p194 }\end{array}$

The research was self financed for doctoral study.

\begin{abstract}
The Kenya is a developing country where $85 \%$ of employment is generated by MSMEs . The country has been experiencing the upsurge of too many challenges all at once. These includes an experimental "coalition government', economic recession, implementing a new constitution, cultural diversity and the animosity behind it. These challenges may impact the performance of enterprises by affecting the management strategies. The study addresses the effects on management strategies such as marketing strategies, human relations strategies, strategic management and interpersonal factors among others. The objective is to test effects of external environment on the internal management strategies within the MSMEs. Results from the study indicated significant correlations between the management strategies and the environmental factors. However, there was no significant effect of the environment on the performance of the MSMEs. It is concluded that the external environment affects performance by affecting the management strategies the firms undertakes. A major control factor will be the nature of the firm and the calibre of management in practice which will dictate strategies undertaken to react to the environment.
\end{abstract}

Keywords: Environmental factors, Management strategies, MSME's (micro, small and medium enterprises), SMEs and MSEs

\section{Introduction}

\subsection{Environmental forces}

It is important to note that organisation performance does not happen in a vacuum but within a certain environment which has challenges and opportunities, (Walter et al 2008: 530-540). Environmental forces create challenges and opportunities for the organization (Gibb 2006:263-283, Pearce \& Robinson 2007:83-114). Managers / owners must react and adapt to changes in their internal and external environment. Globalization is 
an example of an opportunity for an organisation (Maxwell, Rankine \& Macvicar 2007, Pearce \& Robinson 2007:126-127). Improved technologies, such as transportation and communications, have enabled companies to expand into global or worldwide markets. Globalization affects how organisations are managed. Managers must learn to deal effectively with multiple cultures and political systems in the midst of rapidly changing markets and technology. They must be able to anticipate this changing environment and develop the vision and competencies at all levels in their organisations to embrace this dynamic future (Njanja, 2009:10).

The move towards economic liberalization proposed in the late 1980s and 1990s in Kenya was aimed at reducing distortions in the economy; deregulation of markets has had adverse impact on MSEs (Sessional Paper No. 2, 2005). The effects include increased macro-economic instability characterized by high inflation rate, current account deficits and policy uncertainty. While the effects have been harmful to all private enterprises, the MSMEs have been particularly hurt given their small size, and because they have fewer options to ride over instabilities. Secondly, the country has had a highly turbulent political environment in addition to the global economic recession. Clearly, no business large or small operates in a vacuum. All businesses operate within an environment and are also subject to unique internal environs. The objective of this research was to find the impact of the external environment on management strategies.

\section{Research Methodology}

\subsection{Research design}

Mouton (2005: 55-56) discusses three types of research design, namely; exploratory (this emphasizes discovery of ideas and insights), descriptive (concerned with determining the frequency with which an event occurs or relationship between variables), casual (this is concerned with determining the cause and effect relationships). The survey strategy was chosen as the most appropriate method that could provide a broad overview of a sample representing MSMEs that would allow for generalisation (Mouton 2005:152-3).

The study was cross-sectional in the sense that relevant data was collected at a point in time. The reason for preferring a cross-sectional study is the vast nature of the project. Finally, the researcher was dealing with events that have happened and had no control over the variables in terms of being able to control them. This research, therefore, utilized an ex-post facto design because such independent variables as business age, manager's experience or qualifications; gender, business size and type and other business-related factors cannot be manipulated. The research relied on records of events that have already taken place; hence the researcher could not manipulate any causal factors or challenges that the business managers/management pose to business performance.

This research applied a combination of quantitative and qualitative methods of doing research, which has been practised, as recommended by Keggundu et al., (1993:66-4), Thietart et al., 2001: 82-83).

\subsection{Setting and sampling Procedure}

A list was obtained from the Kenya National Chamber of Commerce and Industry (KNCCI) which covers 68 major towns of Kenya. There are 8 provinces in Kenya so stratified random sampling was done to ensure their representation. A total of 10 towns were identified which had the 3 categories of MSMEs and situated within the 8 provinces.

Second, stratified sampling was used to divide the MSMEs into categories according to homogeneity. This ensured that the micro-businesses, the small businesses and the medium businesses were proportionately represented in all towns.

From the three separate lists (that were verified with lists obtained from the Ministry of Labour), systematic sampling was applied to select the respondent businesses. These groupings were meant to ease analysis and give room for comparison of results.

\subsection{Questionnaire Method}

The researcher administered a set of structured and unstructured questionnaires to the sampled group and gave them period of (18) days to respond. She picked the questionnaires on an appointed date and went through the questions with the manager.

\subsection{Data Analysis}

To evaluate the effects of various internal and external factors on the performance of micro, small and medium enterprises, simple regressions and correlation analysis were done using the statistical package for social sciences (SPSS) version 15, SAS Version 9.1. The results are discussed in section 4 of this paper. 


\section{Literature Review}

\subsection{Environmental Factors}

Included under this section are the environmental factors that are basically external and not within the management control, namely, the political/legal, economic, socio-cultural and the technological issues that directly impact on the management of MSMEs. Included under the political/ issues are the policy and institutional factors.

\subsection{Technological Factors}

According to McNamara and Watson, 2005:184-190, technology can be defined as

...the totality of means - means such as knowledge, methods, materials, and tools used to achieve practical outcome. A way for the company to establish work methods, work patterns, and information structures...It is the tools and the means, but not the primary goal or result to be pursued... Technologies have the potential to improve speed, quality and efficiency

In the mainstream of modern culture, technology is considered to be one of the answers to most problems and/or restrictions in business. It is seen as the way that a business can emerge from the past and enter a brighter, more efficient future. There are many and various technologies that could be addressed in terms of benefiting SMEs. For this research, only a specific few will be dealt with in terms of those that are considered to be leading edge and most appropriate for SMEs.

Industrial technology in Kenya is yet to take-off and most MSEs have not even achieved the first level of industrial take-off (Aduda, Kaane and Namusonge, 1999; Namusonge 2004:11). This first level entails encouraging enterprises manufacturing consumer goods to acquire the latest technologies that are efficient in use of materials and utilities in addition to being more environmental friendly.

The challenge facing MSEs in developing countries, Kenya included, is how to move from the relatively informal cottage industries to larger enterprises with stronger technological capacities and performance (Aduda, et al., 1999) Innovation potential exists in many small entrepreneurs. Little funding has gone into 'identifying, documenting, follow-up and financial support for technological change and innovation in MSEs' (Mihyo, 1994). There are serious shortcomings in technology management and there are no systems for promoting goods innovations and information exchange among MSEs and other stakeholders in the sector. One way of achieving this would be through inter-firm linkages.

Although larger enterprise size may seem desirable, the global trend in industrial structure is towards small-sized enterprises (Meyanathan \& Munter in Kata \& Wan 2001:259). Inter-firm linkages are therefore paramount if Kenyan firms are to benefit from increased decentralization and downsizing in the global arena. The policy imperative is, therefore, to create environments and incentives for the formation of industrial structures rich in linkages among MSEs, for example formation of clusters, and between MSEs and large enterprises.

Many SMEs are hoping to set aside more money for technological expansion (Baseline Survey). The majority $65 \%$ of those businesses are doing so because they "are more interested in solving business problems that help them maintain competitiveness and generate profit growth than with implementing technology for technology's sake. SMEs are interested in solutions to their everyday business problems that will allow them to better succeed in their industry. The use of technology in some form is widespread. The problem for most businesses is that they have not fully integrated the technology that they have or are trying to obtain with their business (McNamara, 2005:184-190). They "tend to be tactical, not strategic, in their technology adaptation" (Harney2005:59-66). The competitive advantages that certain technologies bring to existence are very important, especially where there is a high aggressive industry. Small businesses look for new ways that will help them achieve these distinctions. Capitalizing on these technologies would help spur MSMEs forward. Several technologies have been introduced that will help bring about a cost savings for small businesses.

Another area that technology is useful for is helping small businesses in keeping track of inventory and the general bookkeeping (cited earlier as an important factor in success by Ibrahim and Goodwin 1986:41-50).Inventory control has long been a defining factor in determining the wellness of a business. By being able to know exactly what is coming and going a business is better able to plan for the future. Today, businesses have the ability to track exactly where their inventory is in real time. That ability helps them to identify key areas that could be improved or changed in order to limit time between processes or transactions (Berger, 2005: 346). If a business is not as concerned with a real time display, but instead needs to have a better understanding of what their inventory looks like, bar coding may be the better and less costly alternative. 
Many MSMEs have a very local flavour to them and they do not see the "need for connectivity". They address the needs of a very local market and do not recognize any need for expanding their current operations technologically. These businesses do know that adapting new technologies will further benefit their current business model because most of their businesses are done within a small community and their customers rely fully on them for service and product guarantee. Some small business owners or managers are reluctant to enter the technology scene because they are uncertain of the security and privacy concerns that are almost certain to occur. For such business owners, the idea of e-commerce in any shape is too risky for their business. The idea of Internet related business activities or electronic data is not a necessary thing but something to be avoided at all costs.

Other issues relate to the lack of IT professionals, because technology industry seems to be so complicated, there are many companies who do not engage in new technologies due to lack of the expertise on their staff to handle the potential problems that might arise. Mihyo (1994) posits that 'budget for the technology' as seen to be quite expensive and also 'lack of proper infrastructure' (incompatibility between the old and new technology).

Available technologies for SMEs are Voice over Internet Protocol (VoIP) which is a technology that "allows you to make telephone calls using a computer network, over a data network like the Internet" (Chandler, 2005:32-68). The major benefit of VoIP is that it takes what would otherwise be a long distance call and makes it a local call. The reduction in cell phone bills alone for one company can make up for the costs of implementation.

There are several different technologies that fall under the category of data protection. For those networks that are linked both internally and externally, a firewall is necessary to keep would be hackers and pilferers out. Others are file servers (utilized by businesses that have two or more users sharing information between computers. By taking advantage of a file server, SMEs can store more information and applications on their computers, making them more efficient.

Others technological solutions available are the middleware technology that has the capability of merging two systems together and integrating the data between them. This can be an old system and a new one or two new systems coming together in a business merger. Either way, the middleware software applications are relatively inexpensive compared to a complete overhauls of the two systems and require very little maintenance. Another option is for MSMES to hire a consultant who can go through its current business processes and then give suggestions as to what new technologies could benefit it the best. These consultants are usually able to set up and install whatever choices the MSMES make. A final option for MSMES who are choosing to integrate technology is outsourcing. By outsourcing its technological needs, a small business can focus more of its attention on doing what it does best rather than diverting it to another area.

\subsection{Regulation and Policy Issues}

Regulation refers to all mechanisms of social control - including unintentional and non-state processes (Baldwin et al. 2006:243-260). In this context, state regulation can be defined as activities taken by state organisations that mandate or prohibit actions by individuals and organisations, with infringements subject to legal sanction. This would, therefore, include inspection and enforcement (Hampton Review 2005 report).

For business owners, important regulations include state actions relating to the following non-exhaustive list:, contract enforcement, property rights, including intellectual property, corporate governance, taxation and financial reporting, employment and health and safety, trading standards and consumer rights, environmental protection, premises and planning rules, data protection, transport. Some regulations apply to particular types of business. For example, VAT registration in the UK is only compulsory for those trading above the specified turnover threshold (currently £60k per annum). Employment rights are only relevant to those employing, or considering employing, others. Other types of regulation, though universal in their scope, vary in their impact across businesses. Environmental regulations concerning the storage and use of hazardous substance, for example, are likely to have a greater impact on certain sectors than others, for example, agriculture, manufacturing and transport and communications businesses (Carter, Candida, Greene, Gatewood \& Myra. (2003).

Regulatory interventions generate effects through their influence on the resources and reasoning of differently resourced agents, in this case, business owners, through shaping their constrained choices for action (Pawson \&Tilley 1997) in (Kautoo \& Hilden 2004). Critics of state regulation argue that it imposes costs on individuals and businesses that impede business start-up, investment, innovation, employment, business growth and, ultimately weaken national economic performance (HM Treasury/SBS 2002) from which businesses, workers and consumers all suffer. This, of course, will depend on pre-existing business practices at the time a regulatory change comes into effect as well as the regulatory requirements themselves. 


\subsection{Macroeconomic Environment}

Although the move towards economic liberalization proposed in the late 1980s and 1990s was aimed at reducing distortions in the economy, deregulation of markets has had adverse impact on MSEs (Sessional paper). The effects include increased macroeconomic instability characterized by high inflation rate, current account deficits and policy uncertainty. While the effects have been harmful to all private enterprises, the MSEs have been particularly hurt given their small size, and because they have fewer options to ride over instabilities.

\subsection{Incentive Policies}

Trade policy is the most important incentive policy because it provides the link to a market for MSE outputs, and a source of inputs and opportunities to produce within an international production chain (Krugen \& Obstfeld, 2007: 10; Ronge, Ndirangu Nyangito; 2002) since the adoption of an open trade policy in Kenya, MSEs have increasingly been involved in the global market. Imports have increased rapidly and this has meant greater competition for their goods in the local market. Trade liberalization has increased competition at home and this is seen as detrimental to MSEs in Kenya, especially those in textile industries. Similar observations were made in Latin America and Canada (Berry, 1996). The indication for Kenya may be that although general incentive reforms are necessary, they may not be sufficient to foster the growth of MSEs.

Experiences of the more successful industrial performers among developing countries suggest that government interventions, despite their dismal record in many countries, play a vital role if carefully designed and well implemented (Crook, 1992 Report) Incentives geared to promoting competitiveness in world markets, but providing some protection for "infant industries" and building up indigenous capabilities, seem to be the most effective combination. Capabilities should be developed through education, training, technological effort and diffusion in which governments and donors have a role to play because many skill and information markets suffer from market failure. It is important that institutions develop to enable markets to function; markets left alone may not generate the right institutions.

\subsection{Institutional Policies}

An unhealthy incentive environment may exist in form of regulations (Ronge et al., 2002). Regulatory policies may discourage increases in size of operation for firms, even though there may be opportunities to exploit economies of scale. But the cost of registering business, the need to use external accountants to satisfy regulatory requirements, and the time spent dealing with disputes with regulatory agencies can be more expensive per unit of production for MSEs. The informal entrepreneurs in MSEs have frequently borne high costs in the form of harassment for non-compliance, and often run the risk of permanently being put out of business.

The tendency of micro and small scale operators, especially small sellers and producers, to congregate in the dense markets and overcrowded cities makes them prey to city authorities in the effort to clear congestion and pollution. Policies that provide a central location where micro enterprises can share facilities are totally lacking in Kenya. Such policies should entail developing a programme of orderly urban development that accommodate the needs of micro enterprises and discourages dispersal to remote areas, as this will retard the growth of MSEs.

Institutions are the foundation of property rights (Kimenyi, Karingi \&Njuguna 1999). As such, they must give confidence to firms to write contracts and also allow legal recourse to be cost effective so that contracts can be enforced. Institutions provide good protection from arbitrary rules of governments and reduce uncertainty. Unfortunately for Kenyan MSEs, there are indications of instability of property rights, which undermines the effectiveness of contracts. In their study on evaluation of the mechanisms for creating property rights for informal firms in Nairobi, Kimenyi et al,. (1999) showed that the vulnerability of the informal sector property rights to revocation makes law a critical threat and veto point that could be used by extortionist officials to levy taxes on informal enterprises. All these unfavourable features of the external environment for businesses much be addressed because very little success can be achieved through general promotion of MSEs.

\subsection{Poor Infrastructure}

Infrastructure as it relates to provision of access roads, adequate power, water, sewage and telecommunication has been a major constraint in the development of MSEs (Bokea, Dondo and Mutiso, 2000). The public sector has failed to provide a good infrastructure framework which is essential for the growth and development of a competitive private sector. Although several politically inspired attempts have been made to provide good infrastructure, mainly work sheds, for MSMEs this is not often included in town planning. Access roads to MSMEs sites are in poor shape and this has meant higher costs of doing business. Though Sessional Paper No. 1 of 1986 promised expansion of electricity supply and water for all by the year 2000, the situation is far from what was envisaged. Frequent power rationing and water shortages experienced in the late 90s have made it 
difficult for industries, especially those in manufacturing and service sectors. Lack of access to electricity has hindered technological growth for MSMEs given that most modern processes are electrical. The high cost of electricity (including high connection charges) has also been a hindrance to access to power. There is also lack of a clear policy for enhancing power supply to MSMEs.

Availability of reliable water supply makes compliance with health and environmental requirements easier (Nyangito 1996). In terms of environmental conservation, small enterprises are a hazard given that over 60 percent do not have water in their premises and use open spaces, rivers and streams to dispose their waste and affluent. About 78 percent of small enterprises rely on burning or dumping for waste disposal. The infrastructure needs of these MSMEs need to be addressed in order to mitigate on this negative aspect and to increase environmental awareness among MSMEs. However, although respect for environment safety. Although MSMEs may face financial limitations in adopting pollution control systems; they need to be encouraged to adopt cleaner methods of production.

Environmental factors considered here are external namely, the political/legal, economic, social-cultural, environmental factors, regulation and policy issues, and the technological issues. The influence of these factors to the firm performance is very important but it is note worthy that the management has no control over them. Nevertheless, the factors must be closely monitored to ensure that stringent measures are taken within the best time to either take advantage of the opportunities or combat the threats found in the external environment.

\section{Results and Discussion}

The individual variables (C24- Human resource strategies, C25b -Strategic management strategies, C26-Finance Management Strategies, C27- Marketing management strategies, C28- Entrepreneurial Strategies) are regressed against the external factors. These variables represent the internal management strategies. They were tested individually as the dependent variables. This concurs with objective five where the researcher sought to establish the effect of external environment on management strategies within the MSMEs.

The independent variables used below were external environmental factors such as C8 (globalization factors), C29(Technological factors), C30(Macro environmental factors), C32( regulation and policy), C33(Incentives) and C34( Institutional policies). It is understood that such variables must be monitored closely though they are beyond the control of managers (Johnson and Scholes 2006). The dependent variables are the internal management factors.

From table 1, the estimated regression is

$$
\bar{Y}=1.080+0.048(\mathrm{C} 8)+.394(\mathrm{c} 29)+0.118(\mathrm{c} 30)-0.109(\mathrm{c} 33)+0.164(\mathrm{c} 34)+0.111(\mathrm{C} 32)
$$

The variables that significantly affect the outcome of the dependent variable (The human resources strategies) are the constant, technological factors, macroeconomic environment factors and institutional policies.

Table 2 shows the estimated regression equation is

$$
\bar{Y}=1.464+0.128(\mathrm{C} 8)+0.348(\mathrm{c} 29)+.044(\mathrm{c} 30)-0.045(\mathrm{c} 33)+0.060(\mathrm{c} 34)+0.060(\mathrm{C} 34)
$$

Significant parameters in the equation are the constant, Opportunities in globalization (c8), technological factors (c29). They are the factors that contribute to the outcome of the dependent variable (Strategic management factors).

Table 3 shows the estimated regression equation is

$$
\breve{Y}=2.195+0.059(\mathrm{C} 8)+.200(\mathrm{c} 29)+0.059(\mathrm{c} 30)+0.008(\mathrm{C} 32)+0.028(\mathrm{c} 33)+0.047(\mathrm{c} 34)
$$

Significant parameters in the equation are the constant, Opportunities in globalization (c8) C8mean, technological factors (c29). They affect the outcome of the dependent variable (Finances/Capitalization factors).

Table 4 shows the regression equation is:

$$
\widetilde{Y}=1.387+0.046(\mathrm{C} 8)+.309(\mathrm{c} 29)+0.119(\mathrm{c} 30) .014(\mathrm{c} 33) .164(\mathrm{c} 34)-0.005(\mathrm{C} 32)
$$

Several factors significantly affect the outcome of the dependent variable (Marketing management factors). These are the constant, technological factors (c29), macro economic factors (c30) and the institutional policies (c34).

The regression equation from table 5 is

$$
\widetilde{Y}=1.758-0.022(\mathrm{C} 8)-0.022(\mathrm{c} 8)+0.519(\mathrm{c} 29)+0.075(\mathrm{c} 30)+0.067(\mathrm{c} 33)-0.053(\mathrm{c} 34)-0.029(\mathrm{C} 32)
$$


The constant and the technological factors (c29) significantly affect the outcome of the dependent variables (Entrepreneurial management factors)

$\mathrm{R}^{2}$ is 0.382 . Thus $38.2 \%$ of the variations in the dependent variables (Technological factors) are influenced by the independent variables (external factors). $\mathrm{Sig}=0.001$ which shows the regression is significant. The regression equation is:

$$
\widetilde{Y}=1.019+0.004(\mathrm{C} 8)+0.231(\mathrm{c} 29)+0.133(\mathrm{c} 30)+0.228(\mathrm{c} 33)+0.128(\mathrm{c} 34)+0.128(\mathrm{C} 32)
$$

The constant, macroeconomic factor and institutional policies significantly affect the outcome of the dependent variable (table 6).

The regression model is:

$$
\bar{Y}=3.600+0.237(\mathrm{C} 8)-0.082(\mathrm{c} 29)-0.194(\mathrm{c} 30)+0.311(\mathrm{c} 33)+0.080(\mathrm{c} 34)-0.175(\mathrm{c} 32)
$$

The constant, Opportunities in globalization (c8) and incentive policies (c33) significantly affect the outcome of the dependent variable.

\section{Summary and Conclusion}

A model was formed for each strategy using multiple linear regressions. The outcomes are summarized in the following table.

\begin{tabular}{|l|l|l|l|l|l|l|}
\hline Environment & Globalisation & Technology & $\begin{array}{l}\text { Macro } \\
\text { economic } \\
\text { factors }\end{array}$ & $\begin{array}{l}\text { Regulation } \\
\text { and policy }\end{array}$ & Incentives & $\begin{array}{l}\text { Institutional } \\
\text { Policies }\end{array}$ \\
\hline Human resources & & $\sqrt{ }$ & $\sqrt{ }$ & & & $\sqrt{ }$ \\
\hline Strategic management & $\sqrt{ }$ & $\sqrt{ }$ & & & & \\
\hline Finance & $\sqrt{ }$ & $\sqrt{ }$ & $\sqrt{ }$ & & & $\sqrt{ }$ \\
\hline Marketing & & $\sqrt{ }$ & & & & \\
\hline Entrepreneurial & & & & & $\sqrt{ }$ & \\
\hline Interpersonal & $\sqrt{ }$ & & & & & \\
\hline
\end{tabular}

The human resources factor was affected very highly by the technological factors, macro environment and institutional factors. Strategic management factors were affected by globalisation and technological factors. Finance and capitalisation strategies were affected by globalisation factors and technological factors. The marketing management factors were affected by macro environmental and institutional policies. The entrepreneurial factors were affected by technological factors. The interpersonal skills were affected by globalisation and incentives policies.

These internal management strategies are highly dependent on external factors. It was noted earlier in Njanja and Pellisier (2011) that there exist some integrative factors between the strategies.

\subsection{Recommendation}

Protective measures must be obtained to protect especially the micro and small businesses from the adverse effects of the external environment as they are most affected.

Firms must maintain the right mix of practices in the areas of strategic management, human resources, marketing, interpersonal issues, entrepreneurial and others. This coupled with the nature of the firm and the management factors will ensure positive performance.

The caliber of management in practice will dictate strategies undertaken to react to the environment. Managers with high analytical skills will be required to keep abreast with the ever dynamic environment.

\section{References}

Aduda, K., and H. Kaane. (2000). Technology policies and strategies.

Andrew Mullei and A. Bokea (Eds). Micro and small enterprises in Kenya: Agenda for Improving the Policy Environment. Nairobi: ICEG

Baldwin, J.R., W. Chandler, C. Le and T. Papailiadis. (1994). Strategies for Success: Catalogue No.61-523. E. Ottawa, Canada.

Berger, A. (2005). Radio Frequency Identification. Interactive Marketing. London: April-June Vol. 6, Iss. 4, p. 346

Berry, A. (1996). Small and Medium Enterprise (SME) under trade and Foreign exchange liberation: Latin 
America and the Canadian experience and concerns. Canadian journal of Development Studies, XV11. 1

Bokea, C., A. Dondo and J. Mutiso (2000). "Physical infrastructure". In Andrew Mullei and A. Bokea (eds). Micro and small enterprises in Kenya: Agenda for Improving the Policy Environment. Nairobi: ICEG.

Carter, N.M., Candida G.B., and Greene P.C., Gatewood E.and Myra M.H. (2003). Women entrepreneurs who break through to equity financing: The influence of human, social and financial capital. Venture Capital, Vol.5, no.1pp.1-28.

Chandler, C. (2005). Small Companies Gaining Big Benefits from New Communications Technology. Alaska Journal of Commerce, Vol. 29, Iss. 10, p. A3. pp. 32-68

Crook, 1992 Report

Hampton Review Report. (2005). Reducing administrative burdens effective inspection and enforcement. March 2005.

Harney, J. (2005). Enterprise Content Management for SMBS. AIIM E-Doc Magazine. Silver Spring: May/June, Vol.19, Iss. 3, p. 59-66.

Ibrahim A and J.Goodwin. (1986). Perceived causes of success in small business. American Journal of Small Business, 11 (Fall), 41-50.

Johnson G \& Scholes K. (1999). Corporate strategy. London Prentice Hall. Europe. Pp. 67-78.

Johnson, G \& K. Scholes (1997). Exploring corporate strategy. (3rd ed). New York: Prentice Hall.

Keggundu M, Jorgenson J and Hafs T. (1993). Administrative Theory and Practice in Developing Countries: A Synthesis. March 1993, pp66-4.

Kimenyi, S.M., Karingi, S.N., and Ndungu, N.S. (1999). Beer taxation in Kenya: An assessment. ISBN 9966949 097.

McNamara, Kevin and John G. Watson. (2005). The Development of a Team-Oriented Structure in aSmall Business Enterprise. Journal of American Academy of Business. Cambridge Hollywood: March 2005. Vol. 6, Iss. 2, p, 184-190.

Meyer, G.D. (2001). Major Unresolved Issues and Opportunities in Entrepreneurship Education. Coleman Foundation White Paper Series, pp. 5-26

Mihyo, B. P. (1994). Technology policy and the future of small and micro enterprises in Kenya. The Netherlands Government Mission on SED Programme.

Mouton. (2005). Post graduate research. South Africa

Namusonge G. (1999). Determinants of growth-oriented Small and Medium enterprises in Nairobi. Unpublished thesis, JKUAT.

Namusonge G. (2004). The role of development financial institutions in acquiring of technical. capabilities by small and medium enterprises in Kenya. Unpublished Thesis. Jomo Kenyatta University College

National Baseline Survey (1999). National micro and small enterprise baseline survey. Nairobi: ICEG and K-REP, pp10-217.

Njanja W L \& R Pellisier. (2011). The integrative effects of various management strategies in the performance of MSMES. International Business and Management, Vol.2 No.2, 2011.

Njanja W L. (2009). AN investigation into management Strategies affecting performance of Micro, Small and medium Enterprises in Kenya. Unpublished thesis. University of South Africa.

Nyangito, H O. (1996). Policy and legal framework for the coffee subsector and the impact of liberalization in Kenya. ISBN 9966949062.

Nyangito, H. O. (1995). Policy and legal framework for the tea subsector and the impact of liberalization in Kenya. ISBN 9966949054.

Pawson and Tilley. (1997). Realistic Evaluation. London: Sage Publications.

Ronge E, Ndirangu L, \& Nyangito H. (2002). Productive Sector Division, Kenya Institute for Public Policy, Research and Analysis, KIPPRA Discussion Paper No. 20, November 2002. Journal of Business and Entrepreneurship), 9(1), 47-58.

Sessional Paper No. 2 of 2005 on Micro and Small Enterprises for wealth and Employment creation for 
poverty reduction. Kenya.

Thietart et al. (2003). Doing management research. Sage Publishers, London.

Table 1. The human resources strategies (C24)

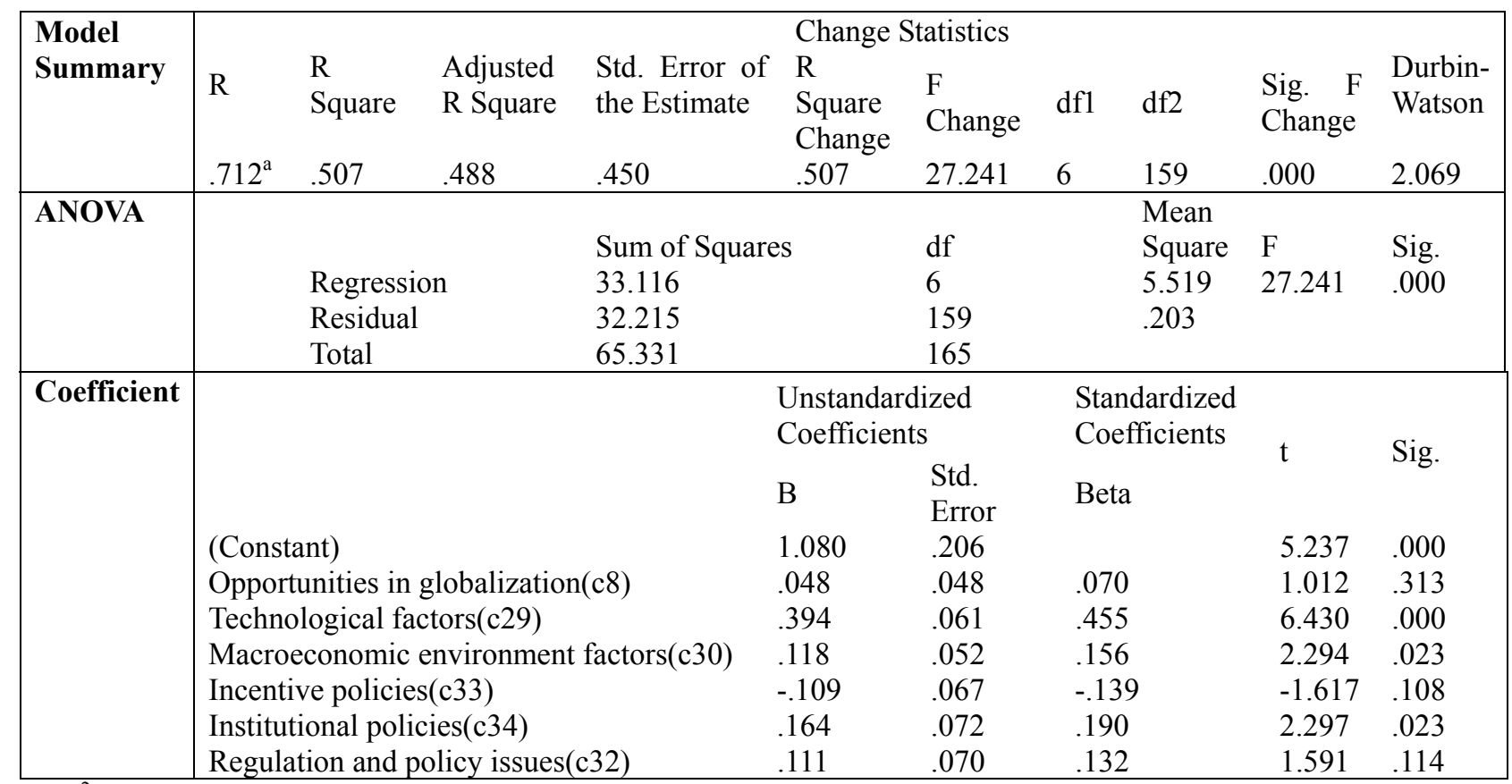

$\mathrm{R}^{2}$ is 0.507 or $50.7 \%$ of the variations in the human resources skills is determined by the external environmental factors. Sig is 0.0001 , which shows the regression is significant.

Table 2. C25b Strategic management factors

\begin{tabular}{|c|c|c|c|c|c|c|c|c|c|c|c|}
\hline $\begin{array}{l}\text { Model } \\
\text { Summary }\end{array}$ & $\mathrm{R}$ & $\begin{array}{l}\mathrm{R} \\
\text { Square }\end{array}$ & $\begin{array}{l}\text { Adjusted } \\
\text { R Square }\end{array}$ & \multicolumn{2}{|c|}{$\begin{array}{l}\text { Std. Error of } \\
\text { the Estimate }\end{array}$} & $\begin{array}{l}\text { Change Sta } \\
\text { R Square } \\
\text { Change }\end{array}$ & $\begin{array}{l}\text { tistics } \\
\text { F Change }\end{array}$ & df1 & df2 & $\begin{array}{l}\text { Sig. F } \\
\text { Change }\end{array}$ & $\begin{array}{l}\text { Durbin- } \\
\text { Watson }\end{array}$ \\
\hline & $.619^{\mathrm{a}}$ & .383 & .360 & \multicolumn{2}{|c|}{.49158} & .383 & 16.467 & \multirow{2}{*}{\multicolumn{2}{|c|}{$\begin{array}{l}6 \\
\text { Mean }\end{array}$}} & .000 & 1.908 \\
\hline \multirow[t]{4}{*}{ ANOVA } & & & & \multirow{2}{*}{\multicolumn{2}{|c|}{$\begin{array}{l}\text { Sum of Squares } \\
23.875\end{array}$}} & & & \multirow{2}{*}{\multicolumn{2}{|c|}{$\begin{array}{l}\text { Square } \\
3.979\end{array}$}} & & \\
\hline & & \multicolumn{2}{|c|}{$\begin{array}{l}\text { Regression } \\
\text { Residual }\end{array}$} & & & 6 & & & & 16.467 & .000 \\
\hline & & Resic & al & \multicolumn{2}{|c|}{38.422} & 159 & & \multicolumn{2}{|c|}{.242} & & \\
\hline & & Total & & 62.2 & & 165 & & & & & \\
\hline \multirow[t]{9}{*}{ Coefficient } & & & & \multicolumn{3}{|c|}{$\begin{array}{l}\text { Unstandardized } \\
\text { Coefficients }\end{array}$} & $\begin{array}{l}\text { Standardi } \\
\text { Coefficie }\end{array}$ & & $\mathrm{t}$ & \multirow{2}{*}{ Sig. } & \\
\hline & & & & & $\mathrm{B}$ & Std. Error & Beta & & & & \\
\hline & & \multicolumn{3}{|c|}{ (Constant) } & 1.464 & .225 & & & 6.503 & .000 & \\
\hline & & \multicolumn{2}{|c|}{$\begin{array}{l}\text { Opportunities in } \\
\text { globalization(c8) }\end{array}$} & & .128 & .052 & .189 & & 2.449 & .015 & \\
\hline & & \multicolumn{3}{|c|}{ Technological factors(c29) } & .348 & .067 & .411 & & 5.192 & .000 & \\
\hline & & \multicolumn{3}{|c|}{$\begin{array}{l}\text { Macroeconomic } \\
\text { environment factors(c30) }\end{array}$} & .044 & .056 & .059 & & .776 & .439 & \\
\hline & & \multicolumn{3}{|c|}{ Incentive policies(c33) } & -.045 & .074 & -.058 & & -.605 & .546 & \\
\hline & & \multicolumn{3}{|c|}{ Institutional policies(c34) } & .060 & .078 & .071 & & .772 & .441 & \\
\hline & & \multicolumn{3}{|c|}{$\begin{array}{l}\text { Regulation and policy } \\
\text { issues(c32) }\end{array}$} & .080 & .076 & .097 & & 1.047 & .297 & \\
\hline
\end{tabular}

$\mathrm{R}^{2}$ is 0.383 . Therefore $38.3 \%$ of variations in strategic management factors are determined by external variables. $\mathrm{Sig}=0.001$ which means the regression is significant. 
Table 3. C26 Finances/Capitalization factors

\begin{tabular}{|c|c|c|c|c|c|c|c|c|c|c|c|}
\hline \multirow[t]{2}{*}{$\begin{array}{l}\text { Model } \\
\text { Summary }\end{array}$} & $\mathrm{R}$ & $\mathrm{R}^{2}$ & $\begin{array}{l}\text { Adjusted } \\
\text { Square }\end{array}$ & \multirow[t]{2}{*}{$\mathrm{R}$} & $\begin{array}{l}\text { Std. Error } \\
\text { of the } \\
\text { Estimate }\end{array}$ & $\begin{array}{l}\text { Change Stat } \\
\mathrm{R} \text { Square } \\
\text { Change }\end{array}$ & $\begin{array}{l}\text { istics } \\
\text { F Change }\end{array}$ & $\begin{array}{l}\mathrm{df} \\
1\end{array}$ & df 2 & $\begin{array}{l}\text { Durbin- } \\
\text { Sig. F } \\
\text { Chang } \\
\text { e }\end{array}$ & Vatson \\
\hline & $.517^{\mathrm{a}}$ & .267 & .240 & & .40977 & .267 & 9.667 & 6 & $\begin{array}{l}15 \\
9 \\
\end{array}$ & .000 & 2.21 \\
\hline ANOVA & \multicolumn{2}{|c|}{$\begin{array}{l}\text { Regression } \\
\text { Residual } \\
\text { Total }\end{array}$} & $\begin{array}{l}\text { Sum o } \\
9.740 \\
26.698 \\
36.438 \\
\end{array}$ & f Squ & ares & & $\begin{array}{l}\mathrm{df} \\
6 \\
159 \\
165\end{array}$ & \multicolumn{2}{|c|}{$\begin{array}{l}\text { Square } \\
1.623 \\
.168\end{array}$} & $\begin{array}{l}F \\
9.667\end{array}$ & $\begin{array}{l}\text { Sig. } \\
.000\end{array}$ \\
\hline \multirow[t]{9}{*}{ Coefficients } & & & & \multicolumn{3}{|c|}{ Unstandardized Coefficients } & $\begin{array}{l}\text { Standardiz } \\
\text { Coefficien }\end{array}$ & & & $\mathrm{t}$ & Sig. \\
\hline & & & & \multicolumn{2}{|l|}{ B } & Std. Error & Beta & & & & \\
\hline & \multicolumn{3}{|c|}{ (Constant) } & \multicolumn{2}{|c|}{2.195} & .188 & & & & $\begin{array}{l}11.69 \\
4\end{array}$ & .000 \\
\hline & \multicolumn{2}{|c|}{$\begin{array}{l}\text { Opportunities } \\
\text { globalization(c8) }\end{array}$} & in & \multicolumn{2}{|c|}{.059} & .044 & .113 & & & 1.342 & .181 \\
\hline & \multirow{4}{*}{\multicolumn{3}{|c|}{$\begin{array}{l}\text { Technological factors(c29) } \\
\text { Macroeconomic } \\
\text { environment factors(c30) } \\
\text { Incentive policies(c33) } \\
\text { Institutional policies(c34) }\end{array}$}} & \multicolumn{2}{|c|}{.200} & .056 & .309 & & & 3.581 & .000 \\
\hline & & & & \multicolumn{2}{|c|}{.059} & .047 & .104 & & & 1.254 & .212 \\
\hline & & & & \multirow{2}{*}{\multicolumn{2}{|c|}{$\begin{array}{l}.028 \\
.047\end{array}$}} & .061 & .047 & & & . 450. & .653 \\
\hline & & & & & & .065 & .073 & & & .722 & .471 \\
\hline & \multicolumn{3}{|c|}{$\begin{array}{l}\text { Regulation and policy } \\
\text { issues }(\mathrm{c} 32)\end{array}$} & .008 & & .063 & .012 & & & .118 & .906 \\
\hline
\end{tabular}

$\mathrm{R}^{2}=0.267$. Therefore, $26.7 \%$ of the variations in the dependent variable are determined by external factors (independent variables). $\mathrm{Sig}=0.001$ which means the regression is significant.

Table 4. C27 Marketing management factors

\begin{tabular}{|c|c|c|c|c|c|c|c|c|c|c|}
\hline \multirow{3}{*}{$\begin{array}{l}\text { Model } \\
\text { Summary }\end{array}$} & \multirow{3}{*}{$\begin{array}{l}\mathrm{R} \\
.684^{\mathrm{a}}\end{array}$} & \multirow{3}{*}{$\begin{array}{l}\mathrm{R} \\
\text { Square } \\
.467 \\
\end{array}$} & \multirow{3}{*}{$\begin{array}{l}\text { Adjusted } \\
\text { R Square } \\
.447\end{array}$} & \multirow{3}{*}{$\begin{array}{l}\text { Std. Error of } \\
\text { the Estimate } \\
.42940\end{array}$} & \multicolumn{2}{|c|}{ Change Statistics } & \multicolumn{4}{|c|}{ Durbin-Watson } \\
\hline & & & & & \multirow{2}{*}{$\begin{array}{l}\mathrm{R} \quad \text { Square } \\
\text { Change } \\
.467\end{array}$} & \multirow{2}{*}{$\begin{array}{l}\text { F Change } \\
23.255\end{array}$} & \multirow{2}{*}{$\begin{array}{l}\text { df1 } \\
6 \\
\end{array}$} & \multirow{2}{*}{$\begin{array}{l}\text { df2 } \\
159\end{array}$} & \multirow{2}{*}{$\begin{array}{l}\text { Sig. F } \\
\text { Change } \\
.000\end{array}$} & \multirow[b]{2}{*}{2.252} \\
\hline & & & & & & & & & & \\
\hline \multirow{3}{*}{\multicolumn{2}{|c|}{ ANOVA }} & & $\begin{array}{l}\text { Sum of } \\
\text { Squares }\end{array}$ & $\mathrm{df}$ & \multicolumn{2}{|l|}{ Mean Square } & \multirow{3}{*}{$\begin{array}{l}\mathrm{F} \\
23.2 \\
55\end{array}$} & \multirow{3}{*}{$\begin{array}{l}\text { Sig. } \\
.000(a)\end{array}$} & & \\
\hline & & $\begin{array}{l}\text { Regressi } \\
\text { on }\end{array}$ & 25.728 & 6 & 4.288 & & & & & \\
\hline & & Residual & $\begin{array}{l}29.317 \\
55045\end{array}$ & $\begin{array}{l}159 \\
165\end{array}$ & .184 & & & & & \\
\hline \multirow{9}{*}{\multicolumn{2}{|c|}{ Coefficients }} & & & & $\begin{array}{l}\text { Unstandardi } \\
\text { Coefficients }\end{array}$ & & $\begin{array}{l}\text { Standarc } \\
\text { Coeffici }\end{array}$ & $\begin{array}{l}\text { dized } \\
\text { ents }\end{array}$ & t & $\mathrm{SiO}$ \\
\hline & & & & & B & $\begin{array}{l}\text { Std. } \\
\text { Error }\end{array}$ & Beta & & l & SIg. \\
\hline & & \multirow{3}{*}{\multicolumn{3}{|c|}{$\begin{array}{l}\text { (Constant) } \\
\text { Opportunities in globalizatic } \\
\text { Technological factors }(\mathrm{c} 29)\end{array}$}} & 1.387 & 197 & & & 7.053 & .000 \\
\hline & & & & & .046 & 046 & .073 & & 1.016 & .311 \\
\hline & & & & & 309 & 059 & 389 & & 5.283 & .000 \\
\hline & & \multicolumn{3}{|c|}{$\begin{array}{l}\text { Macroeconomic envir } \\
\text { factors }(\mathrm{c} 30)\end{array}$} & 119 & 049 & .171 & & 2.414 & .017 \\
\hline & & \multirow{2}{*}{\multicolumn{3}{|c|}{$\begin{array}{l}\text { Incentive policies(c33) } \\
\text { Institutional policies(c34) }\end{array}$}} & .014 & 064 & 019 & & 215 & .830 \\
\hline & & & & & .164 & 068 & 206 & & 2.398 & .018 \\
\hline & & \multicolumn{3}{|c|}{ Regulation and policy issues(c32) } & -.005 & 066 & -.006 & & -.069 & .945 \\
\hline
\end{tabular}

Table 6.39 shows that $\mathrm{R}^{2}=0.467$. This implies that $46.7 \%$ of the variations in the dependent variable (Marketing management strategies) are explained by the independent variables (external factors). Sig $=0.001$, which shows the regression, is significant. 
Table 5. C28 Entrepreneurial management factors

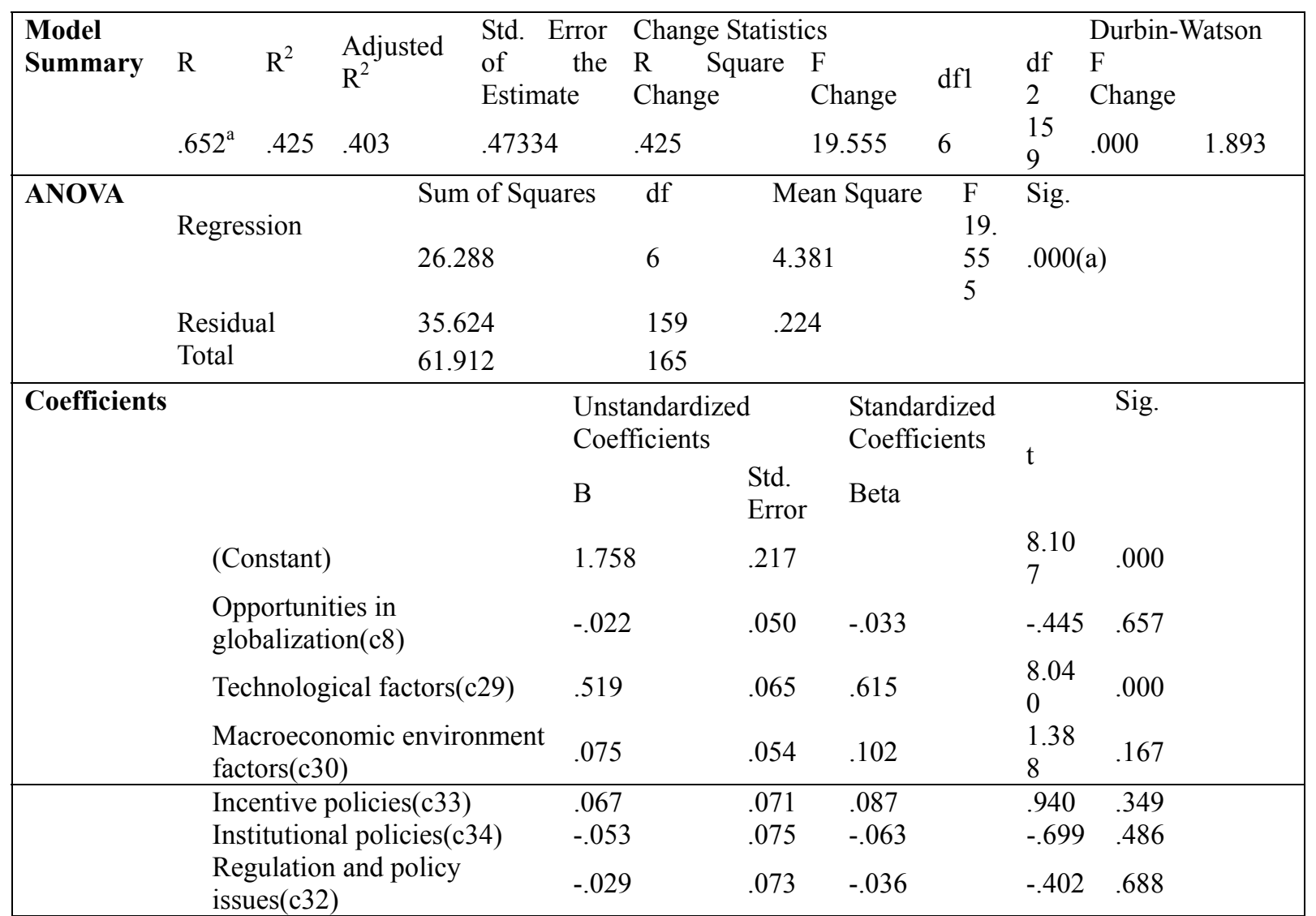

$\mathrm{R}^{2}$ is 0.425 or $42.5 \%$. Therefore, the variations in the dependent variable (Entrepreneurial management factors) are determined by the independent variables. $\mathrm{Sig}=0.001$ which shows the regression is significant.

Table 6. C29 Technological factors

\begin{tabular}{|c|c|c|c|c|c|c|c|c|c|c|}
\hline \multirow{3}{*}{$\begin{array}{l}\text { Model } \\
\text { Summary }\end{array}$} & \multirow[b]{2}{*}{$\mathrm{R}^{2}$} & \multirow{2}{*}{$\begin{array}{l}\text { Adjusted } \\
\mathrm{R}^{2}\end{array}$} & \multirow{2}{*}{$\begin{array}{l}\text { Std. Error } \\
\text { of the } \\
\text { Estimate }\end{array}$} & \multicolumn{6}{|c|}{ Change Statistics } & \multirow[t]{2}{*}{$\begin{array}{l}\text { Durbin- } \\
\text { Watson }\end{array}$} \\
\hline & & & & $\mathrm{R}^{2}$ & & $\mathrm{df}$ & $d f ?$ & Sig. $\quad F$ & & \\
\hline & .382 & .362 & .58003 & $\begin{array}{l}\text { Change } \\
.382\end{array}$ & $\begin{array}{l}\text { Change } \\
19.762\end{array}$ & $\begin{array}{l}1 \\
5\end{array}$ & & $\begin{array}{l}\text { Change } \\
160\end{array}$ & .000 & 2.034 \\
\hline \multirow[t]{4}{*}{ ANOVA } & & & & \multicolumn{2}{|c|}{ Sum of Squares } & df & \multicolumn{2}{|c|}{ Mean Square } & & Sig. \\
\hline & & & \multirow{5}{*}{$\begin{array}{l}\text { Regression } \\
\text { Residual } \\
\text { Total }\end{array}$} & 33.244 & & 5 & 6.64 & & 19.762 & \\
\hline & & & & 53.830 & & & .336 & & & \\
\hline & & & & 87.074 & & 165 & & & & \\
\hline \multirow[t]{9}{*}{ Coefficients } & & & & $\begin{array}{l}\text { Unstan } \\
\text { Coeffic }\end{array}$ & & $\begin{array}{l}\text { Stand } \\
\text { Coeff }\end{array}$ & $\begin{array}{l}\text { dized } \\
\text { ients }\end{array}$ & $\mathrm{t}$ & Sig. & \\
\hline & & & & B & $\begin{array}{l}\text { Std. } \\
\text { Error }\end{array}$ & Beta & & & & \\
\hline & \multicolumn{3}{|c|}{ (Constant) } & 1.019 & .253 & & & 4.027 & .000 & \\
\hline & \multicolumn{3}{|c|}{$\begin{array}{l}\text { Opportunities in } \\
\text { globalization(c8) }\end{array}$} & .004 & .062 & .005 & & .062 & .951 & \\
\hline & \multirow{2}{*}{\multicolumn{3}{|c|}{$\begin{array}{l}\text { Technological factors(c29) } \\
\text { Macroeconomic environment } \\
\text { factors(c30) }\end{array}$}} & .231 & .064 & .263 & & 3.608 & .000 & \\
\hline & & & & .133 & .086 & .147 & & 1.546 & .124 & \\
\hline & \multirow{2}{*}{\multicolumn{3}{|c|}{$\begin{array}{l}\text { Incentive policies(c33) } \\
\text { Institutional policies(c34) }\end{array}$}} & .228 & .090 & .228 & & 2.519 & .013 & \\
\hline & & & & .128 & .089 & .131 & & 1.431 & .154 & \\
\hline & \multicolumn{3}{|c|}{$\begin{array}{l}\text { Regulation and policy } \\
\text { issues(c32) }\end{array}$} & 1.019 & .253 & & & 4.027 & .000 & \\
\hline
\end{tabular}

$\mathrm{R}^{2}$ is 0.382 . Thus $38.2 \%$ of the variations in the dependent variables (Technological factors) are influenced by the independent variables (external factors). $\mathrm{Sig}=0.001$ which shows the regression is significant. 
Table 7. B15.3 Interpersonal skills

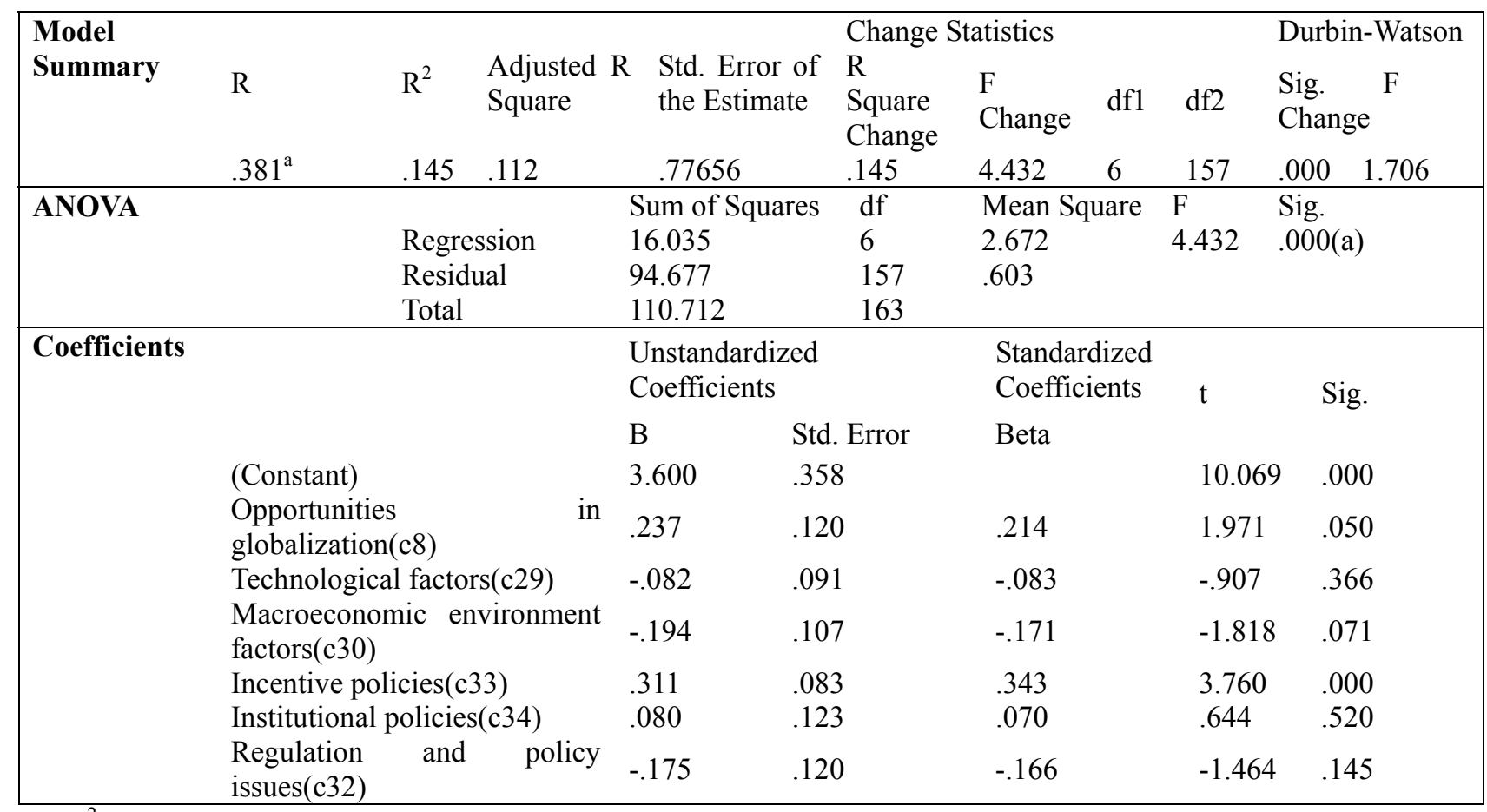

$\mathrm{R}^{2}$ is 0.112 or $11.2 \%$. That implies $11.2 \%$ of the variation in the dependent variable (Interpersonal skills) are determined by the independent variables (external factors). Sig $=0.0001$ which mean the regression is significant.

Table 8. B15.3 Interpersonal skills

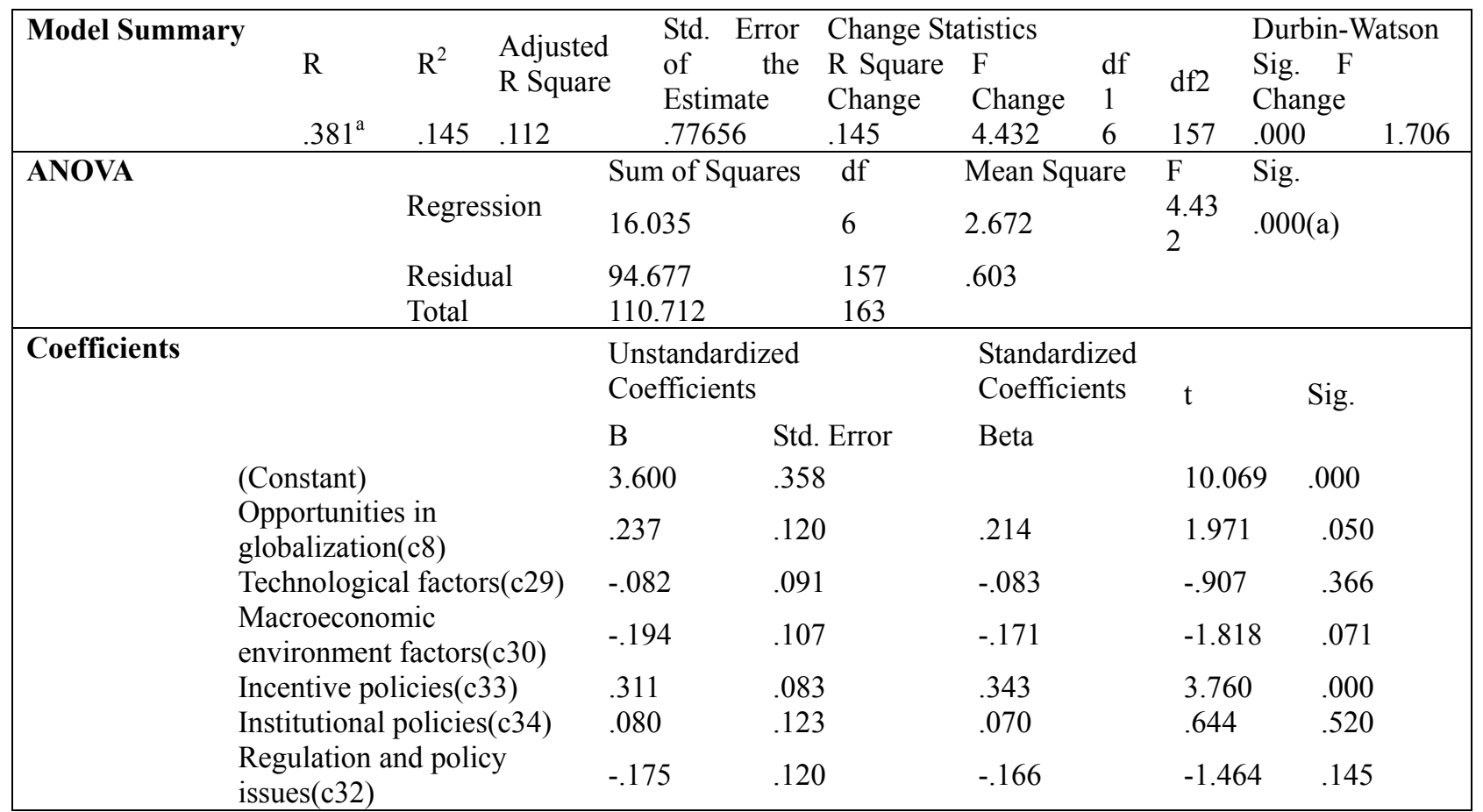

$\mathrm{R}^{2}$ is 0.112 or $11.2 \%$. That implies $11.2 \%$ of the variation in the dependent variable (Interpersonal skills) are determined by the independent variables (external factors). Sig $=0.0001$ which mean the regression is significant. 